\title{
Development of Contextual Teaching and Learning (CTL) Based Learning Devices to Improve Students' Mathematic Problem Solving and Self Efficacy Ability in SMP Negeri 1 Hamparan Perak
}

\author{
Ria Purnama Sari, Nerli Khairani, Edy Surya \\ Mathematics Education, Postgraduate School, State University of Medan \\ Medan, North Sumatra, Indonesia
}

\begin{abstract}
This study aims to: 1) Find learning devices based on contextual teaching and learning (CTL) that can improve students' mathematic problem solving skills at SMP Negeri 1 Hamparan Perak; 2) Find learning devices based on contextual teaching and learning (CTL) that can increase student self-efficacy at SMP Negeri 1 Hamparan Perak; 3) Find practical contextual teaching and learning (CTL) based learning devices that can improve the problem solving and self-efficacy ability of students at SMP Negeri 1 Hamparan Perak; 4) Find learning devices based on contextual teaching and learning (CTL) that are effective to improve the problem-solving ability and mathematic self-efficacy of students at SMP Negeri 1 Hamparan Perak. The results show that: 1) Students' mathematic problem solving ability using learning devices based on contextual teaching and learning (CTL) increased; 2) The increase in students' self-efficacy after using contextual teaching and learning (CTL) based learning devices has increased; 3) The developed contextual teaching and learning (CTL) based learning device met the criteria for practicality of the learning devices; 4) The learning devices developed through contextual teaching and learning (CTL) to improve students' mathematics problem solving ability and self-efficacy have met the criteria of being effective. Keywords: development of learning devices, contextual teaching and learning, problem solving ability, selfefficacy
\end{abstract}

DOI: $10.7176 / \mathrm{JEP} / 12-8-07$

Publication date:March $31^{\text {st }} 2021$

\section{Introduction}

In the mathematics learning process, there are several learning components that affect the achievement of learning objectives. One of the learning components is learning materials. As stated by Suparman (2014: 39) that there are six basic components in learning activities, namely, students, competent graduates as expected, instructional or learning processes, teachers, curriculum and learning materials. Hasyim (2014: 269) states that teachers are an important component in education, namely people who are responsible for educating students' lives and are responsible for all attitudes, behavior and actions in order to foster students to become good and useful people for the country and the nation. in the future. Therefore, teachers are not just teachers but have a conscious and critical meaning in teaching and use their self-awareness to be ready to make changes and improvements in the learning process.

Teachers as implementers of education are expected to have learning devices as guidelines in implementing the learning process in the classroom. The learning device is a device used in carrying out teaching and learning activities in the classroom. The learning devices needed in managing learning in the classroom are in the form of learning implementation plans, student worksheets, evaluation instruments or learning outcomes tests, learning media, and student manuals. Learning devices are the main things that must be used when carrying out learning in class (Trianto, 2009: 201).

As for the importance of learning devices to support the implementation of effective learning so as to create an environment / atmosphere that allows students to learn, to improve student learning outcomes, generate student interest in learning, provide opportunities for students to practice, and to help solve problems experienced by students and have an attitude of appreciating the usefulness of mathematics in life. Learning devices play an important role, as expressed by Suparno (Simanungkalit, 2016: 40) Before the teacher teaches, a teacher is expected to prepare the material to be taught, prepare props / practicum to be used, prepare questions and directions to lure students to actively learn., studying the situation of students, understanding the weaknesses and strengths of students, and learning the students' prior knowledge, all of which will be implemented in the learning devices. Thus, before carrying out learning the teacher should have prepared learning devices. Learning devices are arranged based on the applicable curriculum, adapted to school conditions and student characteristics. The level of quality of learning can be shown by the high involvement of students in learning between teachers and students.

NCTM (Ferrini, 2000: 875) stipulates that there are 5 standard processes that students must master through mathematics learning, namely: (1) problem solving; (2) reasoning and proof (reasoning and proof); (3) 
Communication (communication); (4) Connection; and (5) Representation. The five process standards are known as Daya Mathematics (Mathematical Power), which is the ability to solve problems, both in mathematical problems and problems in real life. Mathematical problem solving ability is the ability to overcome mathematical difficulties by combining previously acquired concepts and rules to achieve the desired goals (Hasratuddin, 2015: 71). The ability to solve student problems in mathematics learning is related to students' self-efficacy. For this reason, students are expected to have problem-solving ability and self-efficacy.

Skaalvik, Federici and Klassen (Sari, 2018: 1239) state that the relationship between student values and motivation is partly mediated through emotional support and self-efficacy. This explanation is in line with the objectives of learning mathematics, namely having an attitude to respect the use of mathematics in real life, curiosity, attention, and interest in learning Mathematics, tenacity and self-confidence. Therefore, self-efficacy must be developed by students in order to interpret the mathematics learning process in real life so that the learning process runs optimally and can help students improve skills to solve math problems. Because of the importance of learning devices in supporting the learning process, the researcher intends to develop learning devices that can improve problem-solving skills and self-efficacy because students who have self-confidence in mathematics tend to be interested and try to study and explore mathematics.

The problem-solving ability that students must build include the ability of students to understand problems, plan problem solving, solve problems according to plans and re-examine procedures for solving results. However, the facts in the field show that the students' problem solving ability is still low. As a research conducted by Shodikin (2014) in a high school in Bandung, it also shows that the results of tests about reasoning skills and mathematical problem solving were carried out by an average score obtained by new students reaching $36 \%$. This shows that the problem solving ability is still low.

The low ability of students to solve mathematical problems was also seen when the researchers conducted preliminary research and observations at SMP Negeri 1 Hamparan Perak. The teacher revealed that most students forgot the basic concepts of the material. When given story questions related to the material, students were unable to solve them; they asked the teacher which formula to use.

To improve students' mathematical problem solving ability and student learning self-efficacy, it is necessary to improve the learning quality. Efforts to improve the learning process through the selection of appropriate and innovative learning models and approaches in mathematics learning in schools is a very important need to do. One of them is in making learning devices; the material presented must be combined with learning models that are in accordance with the needs of students so that learning is more meaningful. Syah (Nugroho, 2017: 34) also explained that the teacher is a factor that affects the condition of students, including the way the teacher delivers the material. For this reason, an innovation effort is needed in the mathematics learning process that is able to facilitate the ability to solve math problems and also the student's self-efficacy. Wiratha (Nugroho, 2017: 34) also said that the learning model used to motivate students is considered relevant to stimulate student interaction and increase self-confidence to solve math problems. One alternative learning model that can be used to make student learning meaningful is to use the Contextual Teacing and Learning (CTL) learning model..

The CTL model refers to the application of mathematics in everyday life, so that students better understand the usefulness of the mathematical concepts they are learning. Sanjaya (Nugroho, 2017: 34) Contextual Teaching Learning (CTL) is a learning approach that emphasizes the process of full student involvement to get material through student real-life situations, thus encouraging students to apply it in their lives. One of the characteristics of the contextual approach begins by exposing students to problems that can make students challenged to solve these contextual problems. Furthermore, this knowledge is constructed by students based on the knowledge they already have. Contextual teaching and learning (CTL) is a conception that helps teachers relate subject content to real-world situations and motivates students to make connections between knowledge and its application in their lives. Trianto (2009: 107) also said that the integration of learning material with the daily context of students in contextual learning will produce the basics of deep knowledge where students are rich in understanding problems and how to solve them. Implementing CTL in a lesson is in principle the same as creating a lesson that challenges students' creativity to find information in learning.

Contextual learning focuses on how students understand the meaning of what they learn, what its benefits are, in what status they are, how to achieve it and how they demonstrate what they have learned. Trianto (2009: 119) says that learning mathematics with contextual learning requires learning to be meaningful and useful for students in their daily lives. Contextual problems that arise in learning use various contexts so as to present situations that have been experienced by students. This process will improve students' ability to solve mathematical problems. So, the reason why choosing the CTL learning model is because it can improve students 'mathematical problem solving ability and also students' learning self-efficacy.

Referring to the descriptions above, the researcher wants to improve mathematics learning that is in accordance with existing needs and resources and has a view of technological developments and the demands of the era of globalization and the curriculum, so there is a need for efforts to "Develop Contextual Teaching and Learning (CTL) Based Learning Devices to Improve Students' Mathematical Problem Solving Ability and Self 
Efficacy at SMP Negeri 1 Hamparan Perak.

\section{Literature Review}

\section{Mathematics Learning and Learning}

According to Slameto (Hamdani, 2010: 20) Learning is a process carried out by a person to obtain new behavior changes as a result of his own experiences in interaction with his environment. AECT (Soeprianto et al: 34) argues that learning is a process in which a person's environment is deliberately managed, allowing learners to participate in certain behaviors under special conditions or generate responses to certain situations. According to Isjoni (2009: 14) Learning is an effort made by educators to help students learn. Learning means a process, way and action of learning something. Learning cannot take place immediately, but through the planning stage. To achieve the specified learning objectives, students are required to be active, independent, and responsible during the mathematics learning process.

\section{Mathematical Problem Solving Ability}

Fauza, Napitulu and Khairani (2019) said that in learning mathematics; not all problems are a problem for one student but can be a problem for others. Regarding Polya's opinion, problems could be challenges or unknown routine procedures. Routine procedures are the process of predicting, finding formulas, and with one or two steps problems can usually be solved.

Problem solving is part of the mathematics curriculum which is very important because in the learning process and its solution students may gain experience using the knowledge and skills they already have to apply to problem solving. This is in accordance with the opinion of Aunurrahman (2009: 254) which states that problem solving is an application and concept of skills. In problem solving usually involves several combinations of concepts and skills in new situations or different situations. The process of solving mathematical problems is one of the basic ability of mathematics that is important to have because the process of solving mathematical problems is the heart of mathematics (Hendriana and Utari, 2014: 23).

Polya (Hendriana and Utari, 2014: 23) details the steps for solving the problem as follows.

1) understanding the problem

2) activities to plan or design problem-solving strategies

3) activities to carry out calculations

4) Activities to check results or solutions.

\section{Self Efficacy}

According to Bandura (Subaidi, 2016: 65), Self Efficacy is an individual's belief in his ability to organize and complete a task needed to achieve certain results. Meanwhile, according to Subaidi (2016: 65) Self Efficacy is a person's belief in his skills and ability in organizing and solving problems for the best results in a particular task. This means that a student's Self Efficacy will be the basis for the student to take action in dealing with a certain problem and the results of his action are an expression of the student's Self Efficacy. According to Bandura (Subaidi, 2016) the dimentions of self efficacy used as the base of the measurement are magnitude/length, strength, and generality.

\section{Contextual Teaching and Learning}

Contextual teaching and learning (CTL) is a conception that helps teachers relate subject content to real-world situations and motivates students to make connections between knowledge and its application in their lives. Trianto (2009: 107) also said that the integration of learning material with the daily context of students in contextual learning will produce the basics of deep knowledge where students are rich in understanding problems and how to solve them.

Trianto (2009: 111) stated that CTL has seven main components, namely contructivism, inquiry, questioning, learning community, modeling, reflection, and authentic assessment.

\section{Development of learning devices}

Learning devices are a set of learning resources that allow students and teachers to carry out learning activities. According to Trianto (2009: 201), learning devices include Learning Implementation Plans, Student Activity Sheets and Evaluation Instruments, which in this study are tests of problem-solving ability with contextual learning of two-variable linear equation system material in class VIII.

\section{Methods}

\section{Research Pattern}

This research is a development research that uses a 4-D development model, namely the stages of defines, design, develop and disseminate. However, in this research it is only carried out in 3-D, namely define, design, develop, 
the fourth stage of designing is not implemented due to limited time and costs.

\section{Participants}

The subjects in this study were students of class VIII SMP Negeri 1 Hamparan Perak.

\section{Data Collection Instruments}

The instruments used in this study included: validation sheets, tests of mathematical problem solving ability, observation sheets of learning implementation, and student response questionnaires.

\section{Data Analysis}

To measure the validity of learning devices, a research instrument was compiled and developed. These instruments are in the form of validity instruments of learning devices, validation sheets for learning implementation plans, validation sheets for student book tests, validation sheets for student worksheets, and validation sheets for tests of mathematical problem solving ability and self-efficacy. To measure the practicality of learning devices, the practical aspects of this developed learning device can be seen from the results of validation by experts, and the results of learning implementation. To measure the effectiveness of learning devices, the criteria for determining the achievement of the effectiveness of the contextual teaching and learning (CTL) learning tool are based on four indicators of learning effectiveness, namely: (1) Achievement of learning completeness if $80 \%$ of students who take the mathematical problem solving ability test have obtained a score of 75 ; (2) the achievement of completeness of learning objectives (at least $75 \%$; (3) the time used in learning is efficient or does not exceed ordinary learning; (4) student responses to learning.

\section{Result \\ Improvement of Students' Mathematical Problem Solving Ability After Using Developed CTL-based Learning Devices}

The improvement of mathematical problem solving ability in the first trial obtained an average N-Gain value of 0.49 in the "medium" category or with a gain percentage of $49 \%$. Based on the first trial, there were no students who got an $\mathrm{N}$-Gain score in the range $>0.7$ or experienced an increase in mathematical problem solving ability in the "High" category. 18 students who experienced an increase in mathematical problem-solving ability in the "moderate" category or got an N-Gain score of $0.3<\mathrm{g} \leq 0.7$ and 4 people who got an $\mathrm{N}$-Gain score $\mathrm{g} \leq 0.3$ or experienced an increase in ability.

Then in the second trial the problem-solving ability with a large increase was in the "medium" category with an average N-Gain value of 0.59 or with a gain percentage of $59 \%$. Based on the second trial, there was also 1 student who got a Gain score in the range $>0.7$ or experienced an increase in problem-solving ability in the "High" category. For students who experienced an increase in problem-solving ability with the "moderate" category or got a gain score of $0.3<\mathrm{g} \leq 0.7$, there were 21 people and none of them got a gain score of $\leq 0.3$ or experienced an increase in problem solving ability with the category " Low".

\section{Students' Self Efficacy after Using the Developed CTL-based Learning Devices}

The increase in student self-efficacy after using contextual teaching and learning (CTL) -based learning devices increased based on the KAM category, it increased from trial I to trial II, in the high group it was 94.67 , it increased to 98 , in the moderate group it was 82.80 increased to 83.47 . In the low group, it was 63.25 , it increased to 64 . Judging from the average achievement of students' self-efficacy in the first trial of 80.86 , it increased to 81.90 in the second trial.

\section{The Practicality of Learning Devices Developed with CTL-based Learning}

In this study, two indicators of practicality were determined, namely the response of the expert team or validator which stated that the learning device was valid, consisting of: (1) the validation results of the average lesson plan (RPP) of 4.14 ; (2) The validation results of the average validity of students' books were 4.03 ; with a valid category. (3) The results of the validation of the average validity of the student activity sheet were 4.00 ; (4) the validation of the problem-solving ability test can be used with small revisions and without revisions, where the overall mean value is at a value of $4 \leq \mathrm{Va}<5$ is in the valid category and the implementation of CTL-based learning devices is at the $\mathrm{IO}=3.09$ criterion while on the test trial I and $\mathrm{IO}=4.26$ high in trial II.

\section{The effectiveness of Learning Devices Developed with CTL-based Learning}

Based on the results of the data analysis of the results of trial I and trial II, it was found that classical student learning completeness had been achieved in the second trial, namely $86.36 \%$, the achievement of learning objectives had been achieved for each item in the second trial, namely question number 1 of $79.26 \%$, question number 2 was $84.38 \%$, question number 3 was $77.56 \%$ and question number 4 was $76.42 \%$, student response was 
92.51\% which showed a positive response to learning devices based on contextual teaching and learning (CTL) that is developed and the learning time used does not exceed the usual learning time set by the school.

\section{Discussion}

\section{Learning Tool Development}

The learning devices developed in this study include Learning Implementation Plans, Student Books, Student Worksheets, problem solving ability tests and student self-efficacy questionnaires. All learning devices developed use CTL-based learning.

\section{Improving Students' Mathematical Problem Solving Ability by Using the Development of Learning Devices} Based on CTL

Based on the results of the analysis of the students 'mathematical problem-solving ability test I and II showed that there was an increase in students' mathematical problem-solving ability. This increase can be seen from the average test results obtained by students' mathematical problem solving ability.

Table 1. Improved students' mathematical problem solving ability

\begin{tabular}{|c|c|c|c|}
\hline \multicolumn{2}{|c|}{ Trial I } & \multicolumn{2}{c|}{ Trial II } \\
\hline N-Gain & Category & N-Gain & Category \\
\hline 0,49 & Sedang & 0,59 & Sedang \\
\hline
\end{tabular}

From table 1.Based on the normalized gain index, it is found that in the first trial there was an increase in the value with moderate criteria with a score of 0.49 and in the second trial there was an increase in the value with moderate criteria with a score of 0.59 . So it can be concluded that the developed CTL-based learning tool can improve students' mathematical problem solving ability.

\section{Increased Self Efficacy after using CTL-based learning devices}

Based on the results of the student self-efficacy analysis in trial I and trial II, it shows an increase in the value of student self-efficacy, this can be seen from the increase in the average value of student self-efficacy on each indicator in trial I to trial II in the table below. .

Table 2. Increasing students' Self Efficacy

\begin{tabular}{|c|l|c|c|}
\hline \multirow{2}{*}{ No } & \multicolumn{1}{|c|}{ Self Efficacy Indicator } & \multicolumn{2}{c|}{ Average of Self Efficacy } \\
\cline { 3 - 4 } & & Trial I & Trial II \\
\hline 1 & Task difficulty level (Level) & 2,67 & 2,80 \\
\hline 2 & Degree of stability, belief or hope (strength) & 2,70 & 2,83 \\
\hline 3 & Broad field of behavior (generality) & 2,72 & 2,85 \\
\hline
\end{tabular}

From table 2, it is found that CTL-based learning devices have a positive impact on increasing student selfefficacy. This shows that the use of learning devices with developed CTL-based learning has an impact on increasing student self-efficacy.

\section{Practicality and effectiveness of learning devices developed with CTL-based learning}

From the results of the data analysis, it was obtained that the CTL-based learning tool developed practically in the second trial, it could be seen from the valid learning device and the implementation of the CTL-based learning device which was at the IO criterion $=4.26$ high. Based on the results of the data analysis, it was found that the learning devices based on contextual teaching and learning (CTL) that were developed had met the effective category in the second trial. This can be seen from the results of data analysis that have met the four effectiveness indicators.

\section{Conclusion}

1. The improvement of students' mathematical problem solving ability using contextual teaching and learning (CTL) based learning devices increased, in terms of: (1) classical completeness of the posttest trial I was $59.09 \%$, increasing to $86.36 \%$ in trial II; and (2) N-Gain in the first trial of 0.49 to 0.59 in the medium category in the second trial.

2. The increase in students' self-efficacy after using contextual teaching and learning (CTL) based learning devices has increased based on the KAM category, it has increased from trial I to trial II, in the high group it is 94.67 , it increases to 98 , in the medium group it is 82,80 increased to 83.47 . In the low group, it was 63.25 , it increased to 64 . Judging from the average achievement of students' self-efficacy in the first trial of 80.86 , it increased to 81.90 in the second trial.

3. Contextual teaching and learning (CTL) based learning devices developed meet the criteria for practicality of learning devices in terms of validity results by experts who state that learning devices consist of: (1) the results of the average validation of the lesson plan are 4, 14; (2) The validation results of the average validity 
of the Student Book were 4.03; with a valid category. (3) The results of the validation of the average validity of the Student Activity Sheet are 4.00; (4) validation of the problem solving ability test can be used with minor revisions and without revisions, where the overall mean value of the whole is at a value of $4 \leq \mathrm{Va}<5$ so that the experts state that the learning device is categorized as valid with a little revision and analysis of the results of the observation of learning implementation. The score obtained in the first trial was 3.09 (category "moderate") and did not meet the criteria for research success. However, after making several revisions, in the second trial the learning feasibility observation score increased to 4.26 ('High' category). So that the developed learning device succeeds in meeting the practicality criteria of the learning device.

4. Learning devices developed through contextual teaching and learning (CTL) to improve students' mathematical problem solving ability and self-efficacy have met the criteria of being effective, in terms of: (1) completeness of classical student learning has been achieved in Trial II, namely 86, 36\%; (2) the achievement of learning objectives has been achieved for each item in the second trial, namely question number 1 of $79.26 \%$, question number 2 of $84.38 \%$, question number 3 of $77.56 \%$ and question number 4 of $76,42 \%$; (3) student responses of $92.51 \%$ have shown a positive response to the developed contextual teaching and learning (CTL) based learning devices; and (4) the learning time used does not exceed the usual learning time set by the school.

\section{REFERENCES}

Aunurrahman. 2009. Belajar dan Pembelajaran. Bandung: Alfabeta

Fauza, A., Napitulu, E.E., dan Khairani, N. 2019. The Enhancement Difference of Eight Grade Students' Mathematical Problem-Solving Ability. AISTEEL 2019. Vol. 384: 1-5

Ferrini, J \& Mundy. 2000. Principles and Standards for School Mathematics: A Guide for Mathematicians. Notices of the $A M S .47(8): 868-876$.

Hamdani. 2010. Strategi Belajar Mengajar. Bandung: CV Pustaka Setia

Hasratuddin. 2015. Mengapa Harus Belajar Matematika? Medan. Perdana Mulya Sarana.

Hasyim, M. 2014. Penerapan Fungsi Guru dalam Proses Pembelajaran. Auladuna. 1(2): 265-276

Hendriana, H dan Utari, S. 2014. Penilaian Pembelajaran Matematika. Bandung: PT. Refika Aditama

Nugroho, I.A dan Suparni. 2017. Eksperimen Pembelajaran ARIAS dengan Pendekatan CTL Terhadap Self Efficacy dan Pemecahan Masalah Matematika. Seminar Matematika dan Pendidikan Matematika UNY.

Purba, G.I.D \& Surya, E. 2019. The Improvement of Student Communication and Mathematical Disposition Ability Through Problem Based Learning Model at UNIMED FMIPA Students. AISTSSE 2018. 18-19. DOI 10.4108/eai.18-10-2018.2287300

Sari, D.P., Syahputra, E \& Surya, E. 2018. An Analysis Of Spatial Ability And Self-Efficacy Of Students In Cooperative Learning By Using Jigsaw At Smas Muhammadiyah 8 Kisaran. American Jurnal of Education Research. Vol. 6 No. 8. Hal. 1238-1244.

Shodikin, Ali. 2015. Peningkatan Kemampuan Pemecahan Masalah Siswa melalui Strategi Abduktif-Deduktif pada Pembelajaran Matematika. Jurnal Matematika Kreatif-Inovatif. 6(2): 101-110

Simanungkalit, R.H dan Surya E. 2016. Pengembangan Perangkat Pembelajaran untuk Meningkatkan Kemampuan Pemecahan Masalah Matematis Siswa SMP Negeri 12 Pematang Siantar. Journal of Mathematics Education, Science and Technology. 1(1): 39-56

Soeprianto, H., Sarjana, IK., \& Hapipi. 2018. "Implementasi Standar Proses pada Pembuatan Rencana Pelaksanaan Pembelajaran Bagi Para Guru di Gugus III Cakranegara” Jurnal Pendidikan dan Pengabdian Masyarakat. 1(1): 34-38

Subaidi, A. 2016. Self Efficacy Siswa dalam Pemecahan Masalah Matematika. Jurnal Sigma. 1 (2): 64-68

Suparman, M A. 2014. Desain Instruksional Modren. Panduan Para Pengajar dan Inovator Pendidikan. Jakarta: Erlangga.

Surya, E., Purba, C., Syahputra, E., Haris, D., Mukhtar., \& Sinaga, B. 2020. Batak Toba culture on mathematics learning process at Medan high school. Journal of Physics: Conference Series. 1-10. doi:10.1088/1742$6596 / 1613 / 1 / 012063$

Trianto. 2009. Mendesain Model Pembelajaran Inovatif Progresif. Surabaya: Kencana 